\title{
PREPARATION OF POLYMERIC NANOPARTICLES USING DIFFERENT STABILIZING AGENTS
}

\author{
FARKLI STABIILIZZASYON AJANLARI KULLANILARAK POLİMERİK \\ NANOPARTIKKÜLLERINN HAZIRLANMASI
}

\section{Tuba ŞENGEL TÜRK, Zerrin SEZGIN BAYINDIR, Ulya BADILLI}

Ankara University, Faculty of Pharmacy, Department of Pharmaceutical Technology, 06100

Tandoğan-Ankara, TURKEY

\begin{abstract}
The objective of this study was to prepare poly (DL-lactide-co-glycolide) (PLGA) nanoparticles by solvent evaporation method and clarify the effect of various stabilizing agents on the properties of nanoparticles. It is essential to use stabilizing agents to obtain stable emulsions during the nanoparticle preparation process. The type and ratio of the stabilizing agents are very effective on the particle size of the final product. Poly(vinyl alcohol) (PVA) and Pluronic polymers are the commonly used stabilizing agents in PLGA nanoparticle preparation. In this study, a series of nanoparticle formulations containing PVA and/or several Pluronic polymers such as Pluronic F127, Pluronic P85, Pluronic F68, and Pluronic L64 as stabilizing agents were prepared. The influence of PVA concentration and Pluronic polymers on the size, shape and zeta potential of the nanoparticles were evaluated. The size and zeta potential of the nanoparticles were significantly affected by the concentration of PVA. Upon Pluronic introduction the monodisperse size distribution of nanoparticles with PVA was changed into polydisperse distributions. The Field Emission Scanning Electron Microscopy (FESEM) showed that nanoparticles were spherical in shape. The surface of the particles were rough due to Pluronic addition. This research showed that the choice of stabilizing agent is a very critical parameter in terms of obtaining nanoparticles with desired properties. Further studies are being planned to evaluate the efficacy of the prepared formulations on carrying problematic hydrophobic active agents.
\end{abstract}

Key words: Polymeric nanoparticles, Nanoparticulate drug delivery systems, Non-ionic surfactants, Poly(vinyl alcohol), Pluronics 


\section{ÖZET}

Bu çalışmanın amacı, çözücü buharlaştırma yöntemi ile poli (DL-laktid-ko-glikolid) (PLGA) nanopartiküllerinin hazırlanması ve bu nanopartiküllerin özellikleri üzerine çeşitli stabilizasyon ajanlarının etkilerinin aydınlatılmasıdır. Stabilizasyon ajanlarının kullanılması, nanopartikül üretim işlemi sırasında stabil emülsiyonların elde edilebilmesi için gereklidir. Stabilizasyon ajanının tipi ve oranı, final ürünün partikül boyutu üzerinde çok etkilidir. Polivinil alkol (PVA) ve Pluronik polimerleri PLGA nanopartiküllerinin üretiminde yaygın olarak kullanılan stabilizasyon ajanlarıdır. Bu çalışmada, stabilizasyon ajanı olarak PVA ve/veya Pluronik F127, Pluronik P85, Pluronik F68 ve Pluronik L64 gibi çeşitli Pluronik polimerleri içeren nanopartikül formülasyonları hazırlanmıştır. PVA konsantrasyonunun ve Pluronik polimerlerinin, nanopartiküllerin büyüklük, şekil ve zeta potansiyeli üzerine etkisi değerlendirilmiştir. PVA konsantrasyonu, nanopartiküllerin büyüklüğ̈̈ ve zeta potansiyeli üzerine önemli ölçüde etkilidir. PVA ile hazırlanan nanopartiküllerin monodispers partikül büyüklüğü dağllımı, Pluroniklerin eklenmesiyle polidispers dağılıma dönmüş̧ür. Alan Emisyon Taramalı Elektron Mikroskobisi (FESEM) hazırlanan nanopartiküllerin küresel şekle sahip olduğunu göstermiştir. Pluronik ilavesine bağll olarak partiküllerin yüzeyinin pürüzlü olduğu gözlenmiştir. Bu araştırma, istenen özelliklere sahip nanopartikülerin elde edilebilmesi için stabilizasyon ajanı seçiminin çok kritik bir parametre olduğunu göstermiştir. Daha ileriki çalışmalarda, hazırlanan formülasyonların, problemli hidrofobik etkin maddelerin taşınmasındaki etkinliğinin değerlendirilmesi planlanmaktadır.

Anahtar kelimeler: Polimerik nanopartiküller, Nanopartiküler ilaç taşıyıcı sistemler, Non-iyonik surfaktanlar, Polivinil alkol, Pluronikler.

\section{INTRODUCTION}

Polymeric nanoparticle-based drug delivery systems are one of the most developing area within nanotechnology. The important technological advantages of nanoparticles used as drug carriers are high stability, high carrier capacity, feasibility of incorporation of both hydrophilic and hydrophobic substances, and feasibility of variable routes of administration, including oral application and inhalation (1-5). Treatment with these systems increases bioavailability, reduces the frequency of administration, and promotes targeting of drugs to specific sites. FDA approved biodegradable polymers such as poly(lactic acid) (PLA), poly(D,Llactide-co-glycolide) acid (PLGA), and poly(caprolactone) (PCL) are the most commonly used polymeric materials for preparing polymeric nanoparticles for the purpose of drug delivery due to the biocompatibility and biodegradability of these materials (6-10). In the recent years, many researchers have studied the preparation methods of PLGA nanoparticles and the formulation parameters, such as the molecular weight of PLGA, lyophilizing agents and stabilizing agents. Among those parameters, stabilizing agents have an important role in the production of nanoparticles. They decrease the interfacial tension between the lipophilic and hydrophilic phases of the nano emulsion and simplify the 
formation of nanoparticles by obtaining emulsion stability during the nanoparticle preparation process (11-13). Surfactants are classified as; anionic (negative charge), cationic (positive charge), zwitterionic or amphoteric (charge depends on the $\mathrm{pH}$ of the medium) and non-ionic (no charge). Among these types of surfactants; non-ionic ones are commonly used in oral pharmaceutical formulations to enhance the bioavailability of particularly water-insoluble agents. Non-ionic surfactants offer several advantages: (i) they are more hydrophobic than ionic surfactants, (ii) they possess a better capacity to dissolve water insoluble drugs, (iii) generally, they are less toxic to biological membranes, and (iv) several non-ionic surfactants have been shown to influence drug pharmacokinetics by modulating efflux pumps such as P-glycoprotein and/or multi-drug resistance associated proteins (14-16).

All surfactants have both hydrophilic and lipophilic properties and are characterized by their hydrophilic-lipophilic balance (HLB) values. HLB system is the relationship (or balance) between the hydrophilic portions of the nonionic surfactant to the lipophilic portion. HLB values of the stabilizing agents affect the qualities of nanoparticles. A stabilizing agent with high HLB can cause destabilization of the double structure while a stabilizing agent with low HLB may lead to instability between globules (17). In this study, various types of Pluronics (Pluronic F127, Pluronic P85, Pluronic F68, and Pluronic L64) and polyvinyl alcohol (PVA) are used as the stabilizing agents. Pluronics (polyethylene oxide-b-polypropylene oxide-b- polyethylene oxide triblock copolymer) and PVA are classified as non-ionic surfactants and have diverse applications in various biomedical fields ranging from drug delivery and medical imaging to management of vascular diseases and disorders. Especially Pluronics interact with multidrug-resistant tumors, resulting in drastic sensitization of the tumors $(9,18-21)$. Objectives of the current study were i) to prepare a series of PLGA nanoparticle formulations by emulsification-solvent evaporation technique with different types and ratios of non-ionic surfactants (plain PVA, plain Pluronic polymers and the mixtures of PVA and Pluronics), ii) to evaluate the influence of PVA concentration and Pluronic polymers on the shape, size and zeta potential of the PLGA nanoparticles.

\section{MATERIALS AND METHODS}

\section{Materials}

PLGA 50:50 [5-15 KDa molecular weight] and PVA 80\% hydrolyzed [9-10 kDa molecular weight] were purchased from Sigma-Aldrich Chemicals Co (Steinheim, Germany). Pluronic F127, Pluronic P85, Pluronic F68 and Pluronic L64 were generous gifts of Basf (Germany). Methylene chloride was purchased from Merck (Darmstadt, Germany) and ultra pure water purified by MilliQ Plus System, Millipore Corp., (Molsheim, France) was used in all experiments. 


\section{Preparation of PLGA Nanoparticles}

PLGA nanoparticles were fabricated by emulsification-solvent evaporation technique (22). $50 \mathrm{mg}$ of PLGA was dissolved in $1 \mathrm{~mL}$ of methylene chloride by one minute of probe sonication (Bandelin Sonopuls HD 2070, Bandelin Elec., Germany) at $10 \mathrm{~W}$. The resulting solution was further emulsified into $20 \mathrm{~mL}$ of aqueous solution containing various amount of surfactant (PVA, Pluronic F 68, F 127, P85, L 64) or surfactant mixtures for 10 minutes by probe sonication at $70 \mathrm{~W}$. After emulsification, the oil-in-water emulsion was magnetically stirred for 24 hours to evaporate the methylene chloride. The nanoparticles formed were then lyophilized for $48 \mathrm{~h}$ (Christ Gamma 2-16 LSC, Martin Christ Gef., Germany). The compositions of nanoparticles are given in Table 1.

Table 1. The compositions of PLGA nanoparticles.

\begin{tabular}{|llllllllllllll|} 
Organic phase & NP1 & NP2 & NP3 & NP4 & NP5 & NP6 & NP7 & NP8 & NP9 & NP10 & NP11 \\
\hline PLGA(g) & 0.05 & 0.05 & 0.05 & 0.05 & 0.05 & 0.05 & 0.05 & 0.05 & 0.05 & 0.05 & 0.05 \\
\hline Methylene chloride(mL) & 1 & 1 & 1 & 1 & 1 & 1 & 1 & 1 & 1 & 1 & 1 \\
\hline Aqueous phase & & & & & & & & & & & \\
\hline PVA(g) & 0.2 & 0.4 & 0.6 & - & 0.2 & - & 0.2 & - & 0.2 & - & 0.2 \\
\hline Pluronic F68(g) & - & - & - & 0.4 & 0.4 & - & - & - & - & - & - \\
\hline Pluronic P85(g) & - & - & - & - & - & 0.4 & 0.4 & - & - & - & - \\
\hline Pluronic F127(g) & - & - & - & - & - & - & - & 0.4 & 0.4 & - & - \\
\hline Pluronic L64(g) & - & - & - & - & - & - & - & - & - & 0.4 & 0.4 \\
\hline Purified water (ml) & 20 & 20 & 20 & 20 & 20 & 20 & 20 & 20 & 20 & 20 & 20 \\
\hline
\end{tabular}

\section{Calculation of HLB Values of Surfactant Mixtures}

The HLB values of the surfactant mixtures were calculated according to the following equation:

$$
\text { HLBmix }=\frac{\left(C_{1} \times H L B_{1}\right)+\left(C_{2} \times H L B_{2}\right)+\left(C_{3} \times H L B_{3}\right) \ldots}{C_{\text {Total }}}
$$

where $\mathrm{C}_{1}, \mathrm{C}_{2}, \mathrm{C}_{3}$ are the percent of component proportion and $\mathrm{HLB}_{1}, \mathrm{HLB}_{2}, \mathrm{HLB}_{3}$ are the HLB values for the each component (23). 


\section{Characteristics of PLGA Nanoparticles}

The size analyses of the nanoparticles were performed using a dynamic light scattering analyzer (Zetasizer Nano ZS, Malvern Inst., Malvern, Worcestershire, UK). This technique yields the mean particle diameter and the polydispersity index (PDI), which is a dimensionless measure of the broadness of the particle size distribution. The nanoparticle formulation was sonicated in ultra pure water to minimize the interparticle interactions and then introduced into the sample dispersion unit. Each nanoparticle formulation was analyzed 3 times with the instrument and the average volume diameter was obtained.

The surface charge of the nanoparticles was also measured by Zetasizer Nano ZS. Prior to the zeta potential measurements, the aqueous diluted suspension of PLGA nanoparticles was sonicated in ultrasonic bath. For each nanoparticle formulation, three measurements were made and the averages of these replicates were calculated.

The zeta potential was automatically calculated by the analyzer using Smoluchowski equation:

$$
m=\frac{\mathrm{e} * \mathbf{z}}{\mathbf{h}}
$$

$\mathrm{z}$ is the zeta potential, $\mathrm{m}$ is the mobility, $\mathrm{e}$ is the dielectric constant, and $\mathrm{h}$ is the absolute viscosity of electrolyte solution (24).

\section{Visualization of PLGA Nanoparticles}

The morphology and shape of the PLGA nanoparticles were investigated by a FEI Nova Nano SEM 430 Field Emission Scanning Electron Microscope (FESEM; FEI, Eindhoven, Netherlands) at $10 \mathrm{kV}$. Before visualization, the lyophilized nanoparticles were fixed on the stub by a double-sided sticky tape and then coated with a platinum layer for $40 \mathrm{~s}$.

\section{RESULTS AND DISCUSSION}

PLGA nanoparticles containing different stabilizing agents were successfully prepared by using emulsification-solvent evaporation technique. This preparation method is a commonly used simple method especially used for obtaining homogenously sized nanoparticles. In this method emulsion formation step is very critical because the droplet size of the emulsion indicates the final nanoparticles size. The droplet size largely depends on the type and amount of the stabilizing agents because they disperse the oil-water phases and provide the stabilization of droplets during the emulsification process $(19,22)$. Due to this fact investigation of stabilizing agents as a critical formulation parameter was aimed in the present study. Within this context, nanoparticle 
formulations were successfully prepared by using different types of Pluronics (Pluronic F127, Pluronic P85, Pluronic F68, and Pluronic L64) and polyvinyl alcohol (PVA). The formulations were characterized in terms of particle size, size distribution, zeta potential and morphology.

The compositions and the characteristics of the prepared PLGA nanoparticles and also the HLB values of the non-ionic surfactants and the surfactant mixtures used in the nanoparticle formulations are given in Table 2. PVA was selected as the reference non-ionic surfactant because of its popularity on the production of PLGA nanoparticles. In this study, three different concentration of PVA (1\%-2\%-3\%) were investigated. It was shown that the concentration of PVA has significantly changed the size and zeta potential of the nanoparticles (Table 2) and its optimum utilization ratio was found to be $2 \%$ because it gave the smallest nanoparticles $(167,9 \pm 0,939)$ with narrow size distribution (PDI $=0,132 \pm 0,006$ ). In order to compare PVA with Pluronics, various formulations were prepared with Pluronic polymers as solely at a rate of $2 \%$ or in combination with $1 \%$ PVA. Both the size and PDI values were increased in nanoparticle formulations prepared with Pluronics as stabilizing agents.

Table 2. Surfactant type, utilization ratio of surfactant, HLB values of the surfactants and the surfactant mixtures used in the PLGA nanoparticle formulations and the physical characteristics of the final formulations.

\begin{tabular}{|llcccc|}
\hline Formulation & Stabilizing Agents & HLB & $\begin{array}{c}\text { Size } \pm \text { SD }(\mathrm{nm}) \\
(\mathrm{n}=3)\end{array}$ & $\begin{array}{c}\text { PDI } \pm \text { SD } \\
(\mathrm{n}=3)\end{array}$ & $\begin{array}{c}\text { Zeta } \pm \text { SD }(\mathrm{mV}) \\
(\mathrm{n}=3)\end{array}$ \\
\hline NP1 & PVA (1\%) & 18 & $203.5 \pm 1.311$ & $0.239 \pm 0.004$ & $-23.4 \pm 0.387$ \\
\hline NP2 & PVA (2\%) & 18 & $167.9 \pm 0.939$ & $0.132 \pm 0.006$ & $-12.4 \pm 0.479$ \\
\hline NP3 & PVA (3\%) & 18 & $227.0 \pm 0.862$ & $0.194 \pm 0.005$ & $-15.35 \pm 0.020$ \\
\hline NP4 & Pluronic F 68 (2\%) & 29 & $286.8 \pm 8.250$ & $0.560 \pm 0.045$ & $-26.0 \pm 1.530$ \\
\hline NP5 & Pluronic F 68 (2\%) & 25.4 & $299.9 \pm 5.265$ & $0.463 \pm 0.027$ & $-26.4 \pm 0.589$ \\
\hline NP6 & PVA (1\%) & 16 & $282.4 \pm 7.823$ & $0.523 \pm 0.020$ & $-31.1 \pm 1.300$ \\
\hline NP7 & Pluronic P 85 (2\%) & 16.7 & $233.5 \pm 1.795$ & $0.339 \pm 0.005$ & $-23.4 \pm 1.720$ \\
\hline NP8 & Pluronic P 85 (2\%) & & & $-27.1 \pm 0.672$ \\
\hline NP9 & PVA (\%1) & Pluronic F 127 (2\%) & $228.0 \pm 8.210$ & $0.418 \pm 0.009$ & $-25.2 \pm 1.510$ \\
\hline NP10 & Pluronic F 127 (2\%) & 20.7 & $271.4 \pm 10.109$ & $0.526 \pm 0.043$ & \\
\hline NP11 & PVA (1\%) & & & & $-42.9 \pm 0.220$ \\
\hline & Pluronic L 64 (2\%) & 15 & $316.3 \pm 2.854$ & $0.422 \pm 0.031$ & $-9.46 \pm 0.128$ \\
\hline
\end{tabular}


The nano size of the particular systems provides higher surface area/volume ratio, easy penetration and permeation through the physiological barriers such as skin, intestine, mucosal membranes (18). The particle sizes were obtained in a range from 316.3 to $228.0 \mathrm{~nm}$ for the formulations which prepared with plain Pluronic polymers. The monodisperse size distribution of nanoparticles with PVA was changed into polydisperse distributions upon Pluronic introduction. A polydisperse size distribution was present in all nanoparticles prepared by Pluronics regardless of PVA.

The zeta potential of the particular drug carrier systems is a very important parameter that effects the physical stability and in vivo fate of the carriers $(1,24)$. The surface charges of the nanoparticles were ranged between -9.46 and -42.9 . The zeta potential values were decreased when PVA was used in a combination with Pluronic L 64 and P 85. On the other hand, the surface charge of the nanoparticles was not significantly affected from the presence of PVA for nanoparticles prepared with Pluronic F 68 and F 127. This situation could be explained on the basis of the length of the hydrophilic chain of Pluronics. The efficiency of PVA on reducing the charge of nanoparticles was found to be less in nanoparticles prepared with Pluronics having longer hydrophilic chain.

Figure 1 shows the correlation between HLB values of surfactants and the characteristics of nanoparticles prepared with plain Pluronics (NP4-NP6-NP8-NP10). A graphical representation of the correlation between HLB values of surfactants and various characteristics of nanoparticles prepared by combining PVA and Pluronic polymers (NP1, NP4-NP11) are also given in Figure 2. The correlation between the physical characteristics of nanoparticles and HLB values of surfactants/surfactant mixtures were reduced when PVA was combined with Pluronics. 

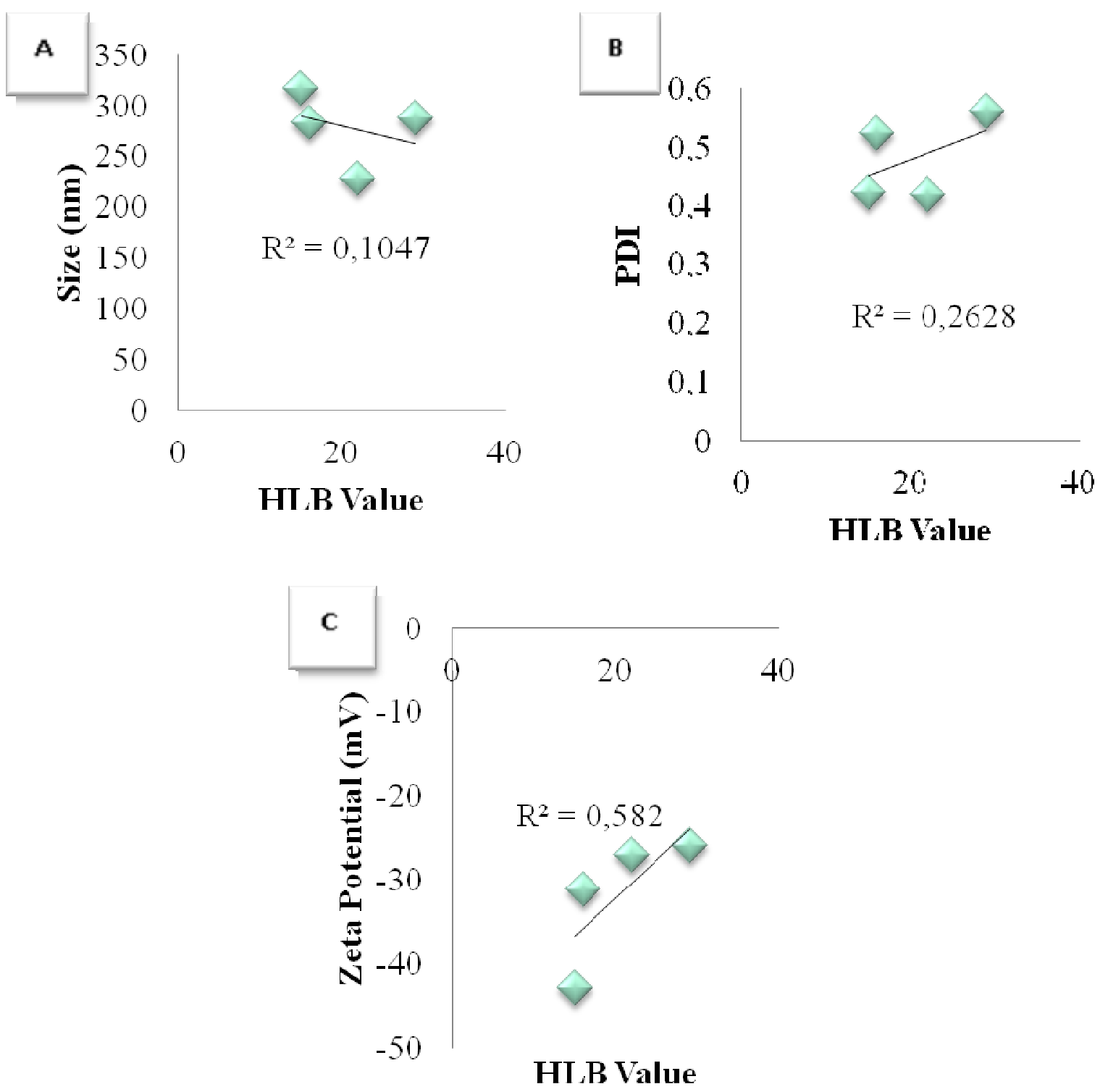

Figure 1. Correlation graphics between the surfactant HLB values and a) the size, b) PDI, c) zeta potential values of PLGA nanoparticle formulations prepared by plain Pluronics as stabilizing agent. 

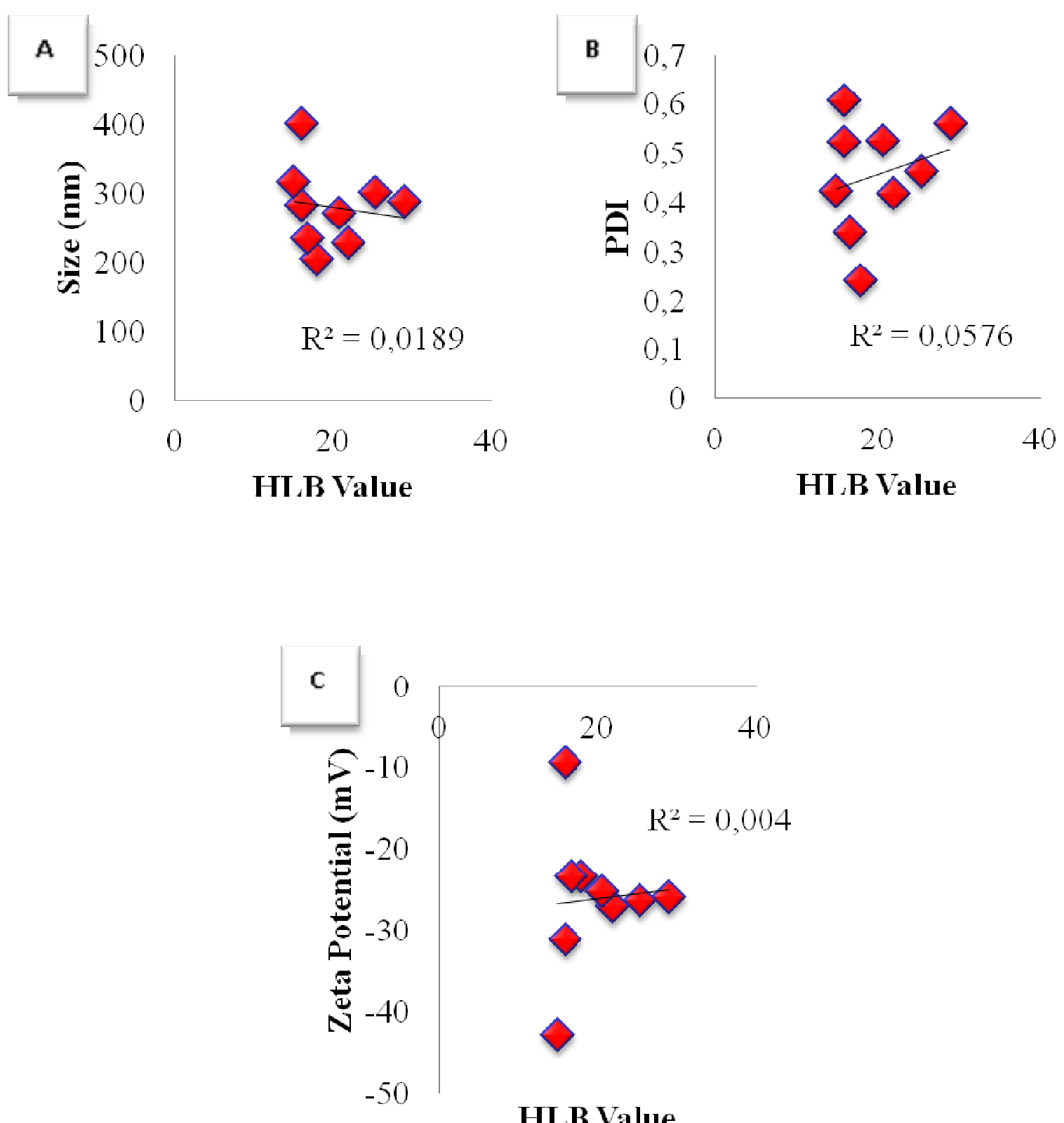

Figure 2. Correlation graphics between the surfactant HLB values and a) the size, b) PDI, c) zeta potential values of PLGA nanoparticle formulations prepared by combining PVA and Pluronics as stabilizing agents.

Figure 3 represents the micrographs of PLGA nanoparticles obtained by FESEM. It was found that all of the nanoparticle formulations were spherical in shape. It was previously shown that PLGA nanoparticles prepared by using PVA own smooth surfaces (10). On the contrary the surface of the nanoparticles prepared by Pluronics was porous. This result is compatible with the 
literature emphasizing that Pluronics strongly get adsorbed onto the nanoparticles surface and result in rough nanoparticles surface (1). This high adsorption is attributed to hydrophobic poly ethylene oxide blocks in Pluronic structure.

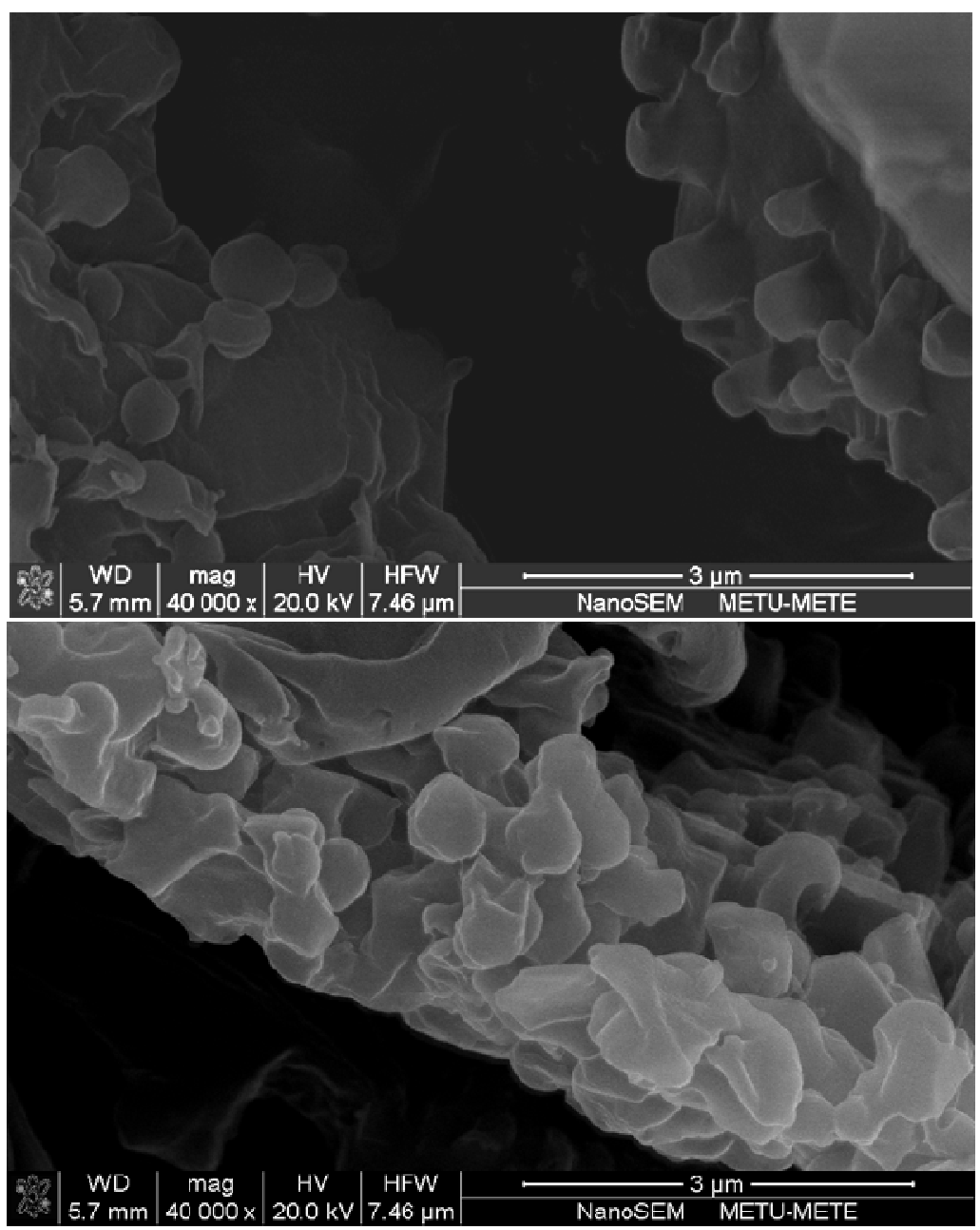

Figure 3. Micrographs of selected PLGA nanoparticle formulation (NP9).

In conclusion, the outcomes of this research revealed that nanoparticles with desired surface charge and particle size can be prepared by changing the type and concentration of the stabilizing agents. The manufacturing process followed in this research is suitable for both of hydrophilic and hydrophobic drugs. The major problem with the administration of many drugs is their formulation problems which lead low bioavailability. Treatments with nanoparticle systems may lead enhanced bioavailability, reduced administration frequency and even promote drug targeting. It would be worth to evaluate the prepared nanoparticle systems in terms of their efficiency on carrying problematic active agents. 


\section{REFERENCES}

1. Yan, F., Zhang, C., Zheng, Y., Mei, L., Tang, L., Song, C., Sun, H., Huang, L. "The effect of poloxamer 188 on nanoparticle morphology, size, cancer cell uptake, and cytotoxicity" Nanomedicine 6, 170-178 (2010).

2. Cohen-Sela, E., Chorny, M., Golomb, G. "Nanoparticles for the treatment of restenosis" in Nanoparticles for Pharmaceutical Applications, Domb, A.J., Tabata, Y., Ravi Kumar, M.N.V., Farber, S. (Eds.), American Scientific Publishers, California, 123, (2007).

3. Şengel, C.T., Hasçiçek, C., Gönül, N. "Design of vitamin E d-a tocopheryl polyethylene glycol 1000 succinate-emulsified poly (DL-lactide-co-glycolide) nanoparticles: Influence of duration of ultrasonication energy" J. Young Pharm. 3(3), 171-175 (2011).

4. Varshosaz, J., Soheili, M. "Production and in vitro characterization of lisinopril loaded nanoparticles for the treatment of restenosis in stented coronary arteries" J. Microencapsul. 25(7), 478-486 (2008).

5. Şengel-Türk, C.T., Hasçiçek, C. "Polimerik Nanopartiküler İlaç Taşıyıcı Sistemlerde Yüzey Modifikasyonu” J. Fac. Pharm. Ank. 38(2), 137-154 (2009).

6. Vega, E., Egea, M.A., Valls, O., Espina, M., Garcı'A, M.L. "Flurbiprofen loaded biodegradable NPs for ophtalmic administration” J. Pharm. Sci. 95(11), 2392-2405 (2006).

7. Badilli, U., Şen, T., Tarimci, N. "Microparticulate based topical delivery system of clobetasol propionate" AAPS PharmSciTech, 12(3), 949-957 (2011).

8. Murakami, H., Kobayashi, M., Takeuchi, H., Kawashima, Y. "Utilization of poly(DLlactide-co-glycolide) nanoparticles for preparation of mini-depot tablets by direct compression" J. Control. Release, 67, 29-36 (2000).

9. Xu, Q., Crossley, A., Czernuszka, J. "Preparation and characterization of negatively charged poly(lactic-co-glycolic acid) microspheres” J. Pharm. Sci., 98(7), 2377-2389 (2009).

10. Şengel-Türk, C.T., Hasçiçek, C., Dogan. A.L., Esendagli, G., Guc, D., Gönül, N. "Preparation and in vitro evaluation of meloxicam-loaded PLGA nanoparticles on HT-29 human colon adenocarcinoma cells" Drug Dev. Ind. Pharm., 38(9), 1107-1116 (2012).

11. Zhang, Z., Feng, S-S. "Nanoparticles of poly(lactide) / vitamin E TPGS copolymer for cancer chemotherapy: synthesis, formulation, characterization and in vitro drug release" Biomaterials, 27, 262-270 (2006).

12. Salager, J.L. Surfactants types and uses, Firp Booklet, Venezuela, p.2 (2002). 
13. Corrigan, O. I., Xue, L. "Quantifying drug release from PLGA nanoparticulates" Eur. J. Pharm. Sci., 37, 477-485 (2009).

14. Wempe, M.F., Wright, C., Little, J.L., Lightner, J.W., Large, S.E., Caflisch, G.B., Buchanan, C.M., Rice, P.J., Wacher, V.J., Ruble, K.M., Edgar, K.J. "Inhibiting efflux with novel non-ionic surfactants: rational design based on vitamin E TPGS” Int. J. Pharm., 370, 93-102 (2009).

15. Dai, W-G., Dong, L.C., Li, S., Deng, Z. "Combination of pluronic / vitamin E TPGS as a potential inhibitor of drug precipitation" Int. J. Pharm., 355, 31-37 (2008).

16. Narang, A.S., Delmarre, D., Gao, D. "Stable drug encapsulation in micelles and microemulsions" Int. J. Pharm., 345, 9-25 (2007).

17. Vandervoort, J., Yoncheva, K., Ludwig, A. "Influence of the homogenizaton procedure on the physicochemical properties of PLGA nanoparticles" Chem. Pharm. Bull., 52(11), 1273-1279 (2004).

18. Zhang, Z., Feng, S-S. "The drug encapsulation efficiency, in vitro drug release, cellular uptake and cytotoxicity of paclitaxel loaded poly(lactide)-tocopheryl polyethylene glycol succinate nanoparticles" Biomaterials, 27, 4025-4033 (2006).

19. Mu, L., Feng, S-S. "PLGA / TPGS nanoparticles for controlled release of paclitaxel: effects of the emulsifier and drug loading ratio" Pharm. Res., 20(11), 1864-1872 (2003).

20. Vandervoort, J., Ludwig, A. "Biocompatible stabilizers in the preparation of PLGA nanoparticles: a factorial design study" Int. J. Pharm., 238, 77-92 (2002).

21. Shah, N., Chaudhari, K., Dantuluri, P., Murthy, R.S.R., Das, S. "Paclitaxel loaded PLGA nanoparticles surface modified with transferin and pluronic P85, an in vitro cell line and in vivo biodistribution studies on rat model” J. Drug Target., 17(7), 533-542 (2009).

22. Keum, C.G., Noh, Y.W., Baek, J.S., Lim, J.H., Hwang, C.J., Na, Y.G., Shin, S.C., Cho, C.W. "Practical preparation procedures for docetaxel-loaded nanoparticles using polylactic acid-co-glycolic acid” Int. J. Nanomedicine, 6, 2225-2234 (2011).

23. http://www.jwsolutions.com/formulationtools Erişim tarihi: 07.06.2012.

24. Bayindir-Sezgin, Z., Yuksel, N. "Characterization of niosomes prepared with various nonionic surfactants for paclitaxel oral delivery” J. Pharm. Sci., 99, 2049-2060 (2010).

Received $=17.12 .2012$

Accepted $=27.11 .2012$ 